\title{
Genetic Component Analysis for a Decade of G. hirsutum Cotton Breeding Material Sponsored in All India Coordinated Cotton Improvement Project
}

\author{
S.L. Ahuja ", S.K. Sain, R.A. Meena and Sarfraz Ahmad \\ Central Institute for Cotton Research, Regional Station, Sirsa, Haryana-125055, India \\ *Corresponding author
}

\section{Keywords}

Genetic gain, Genotypic coefficient of variation, Heritability, Phenotypic coefficient of variation

Article Info

Accepted:

12 September 2018 Available Online:

10 October 2018

\section{A B S T R A C T}

For the proper utilization of the national breeding material sponsored in the All India Coordinated Cotton Improvement Project (AICCIP) of the Indian Council of Agricultural Research (ICAR), the study was conceived to examine the variability, heritability and genetic gain over a decade period (2003 to 2012) for the progress achieved for enhancing the productivity. The field experiments were conducted during these years of Kharif seasons on 27, 31, 32, 40, 40, 36, 39, 42, 42 and 45 genotypes in randomized complete block design with three replications at Central Institute for Cotton Research, Regional Station, Sirsa, Haryana. For a decade within all the years Genotypic coefficient of variation were found almost lower than the phenotypic coefficient of variation for all the traits viz., seed cotton yield, ginning outturn percent, lint yield, boll no. per plant and boll weight indicating preponderance of environmental variation over genotypic variation. For all the years, heritability (85.04 to $99.46 \%$ and 78.94 to $99.54 \%$ ) and genetic gain (417.8 to 897.83 and 152.20 to 300.05 ) values were very high for seed cotton yield and lint yield respectively. Genetic gain was low to moderate for ginning outturn\%, boll no. per plant and boll weight for all the years ranging from 0.90 to $2.36,2.28$ to 7.24 and 0.22 to 1.80 respectively, though for these traits heritability was very high similar to seed cotton yield and lint yield. The study suggested operation of additive gene action for seed cotton yield and lint yield and both additive and non-additive gene action for ginning outturn, boll no. per plant and boll weight. Comparison of genetic component analysis from the average over ten years indicated that during 2003 seed cotton yield, lint yield and boll no. per plant were significantly higher than the average whereas in 2012 seed cotton yield, lint yield and boll weight were significantly higher than this average. The study also indicated from the experimentation on the material sponsored by the breeders in the initial evaluation trial of G. hirsutum (irrigated) over a decade that there was no specific trend for enhancement of seed cotton yield and its component traits under study.

\section{Introduction}

Cotton is an important fibre yielding crop of global importance, which is grown in tropical and subtropical regions of more than 80 countries the world over. It provides livelihood to about sixty million people and is an important agricultural commodity providing remunerative income to millions of farmers both in developed and developing countries. In India, in spite of severe competition from synthetic fibres in recent 
years, it is occupying the premiere position with 70 per cent share in the textile industry.

The All India Coordinated Cotton Improvement Project (AICCIP) of the Indian Council of Agricultural Research (ICAR) is carrying out research work on various aspects of Crop Improvement. The compilation of results of multi-location trials under AICRP on cotton comprises the research work carried out in eleven main centres and ten sub centres located in sixteen State Agricultural Universities all over the cotton growing states of our country. Besides, many voluntary centres of AICCIP and various private sector $\mathrm{R} \& \mathrm{D}$ centres also volunteered to conduct certain specific breeding trials. Under initial evaluation trial of $G$. hirsutum (irrigated) promising breeding material is sponsored every year by the cotton breeders of the country. Each center is given opportunity to sponsor a maximum of two entries per year. The breeding material under this trial is evaluated along with the zonal check and local check varieties for seed cotton yield and its component traits over the different locations of three cotton growing zones. Central Institute for Cotton Research, Regional Station, Sirsa, Haryana is one of the volunteer centre for evaluation of entries sponsored by the breeders of the country. In the multilocation trial conducted under All India Coordinated Cotton Improvement Project, several cotton cultivars are evaluated at National level and Zonal level along with the zonal check and local check varieties every year. Based on the average performance of the cultivar, the best performing cultivars vis-a-vis the check varieties are promoted and then released based on their over the years performance. While promoting the cultivars major emphasis is given to their ranking in yield potential.

Cotton is highly responsive to changes in temperature, humidity, and soil moisture, which may affect its yield, yield components and fiber properties. Climatic, soil, insect, disease and cultural conditions differ from one place to another, and also differ from year to year at the same location. Therefore, genetic and environmental variability for cotton yield, yield components and lint quality traits should be estimated at different environments to conduct successful breeding program. Generally, the magnitude of heritability is influenced by variability between populations, the extent to which a particular character is affected by prevailing environmental conditions of that experiment. Because of this limitation, some workers questioned the wisdom of estimating heritability. However, it can be argued that if a number of estimates for a certain character were made under different environments, a general idea could be formulated about range and magnitude of heritability for that character. Such general knowledge would be useful in indicating the ease or difficulty in attaining effective selection on the basis of phenotypic performance.

Heritability in itself provides no indication about the genetic progress that would result from selection. However, at a fixed selection pressure, the amount of advance varies with magnitude of heritability. Genetic advance in a population cannot be predicted from heritability alone, the genetic gain for specific selection pressure has to be worked out. Many investigations had been made on heritability for seed cotton yield and other traits. Basbag and Gencer (2004) indicated that seed cotton weight had high heritability; bolls per plant had low heritability, while other characters had moderate heritability. The characters with high heritability suggested some possibilities in obtaining required genotypes by selection in early segregating generations (F2, F3); while selection for improvement was delayed due to low heritability for some characteristics. Basal and Turgut (2005) mentioned that moderate 
heritability estimates were observed for lint $\%$ (0.40), however, bolls per plant and seed cotton weight per plant showed low heritability estimates, 0.33 and 0.22 , respectively.

Genetic component analysis picture of evaluation of breeding material developed and sponsored in initial evaluation trial of $G$. hirsutum (irrigated) over the years shall provide the progress made in time and space by the breeders in respect of seed cotton yield and its component and serve as a pathway to progress for the components which are bottle neck for enhancing seed cotton yield. This article includes genetic component analysis of seed cotton yield and its component traits for breeding materials sponsored by different centres over a decade and evaluated at Central Institute for Cotton Research, Regional Station, Sirsa, Haryana.

\section{Materials and Methods}

Experiments were conducted at Central Institute for Cotton Research, Regional Station, Sirsa, Haryana in randomized block design for a decade period during the years 2003 to 2012 and the material consisted of 27 , $31,32,40,40,36,39,42,42$ and 45 genotypes sponsored by different centres of AICCIP during these years in the initial evaluation trial of G. hirsutum (irrigated). Recommended agronomic practices were followed for raising the crop in the month of May. Each genotype was grown in two rows of three replication with row length of $6 \mathrm{~m}$ keeping plant to plant and row to row distance as $30 \mathrm{~cm}$ and $100 \mathrm{~cm}$ respectively.

Observations were recorded on number of total bolls, boll weight (g), seed cotton yield/ha $(\mathrm{Kg})$ and ginning out turn per cent (GOT \%) and lint yield. The mean values were used for the analysis of variance. The analysis of variance was done following the method of Panse and Sukhatme (1978). Genetic component analysis was carried out on mean data following Singh and Chaudhary (1985). The Microsoft Excel computer programme was used to analyze the data. The genotypic variance $\left(\sigma^{2} g\right)$ and phenotypic variance $\left(\sigma^{2} p\right)$ were estimated using following formulae

$\sigma^{2} \mathrm{~g}=\mathrm{Mv}-\mathrm{Me} / \mathrm{r}$

$\sigma^{2} p=\sigma^{2} g+\sigma^{2} e$

Where, $\mathrm{Mv}$ is the mean sum squares attributed to varietal differences (genotypic differences) and $\mathrm{Me}$ is the mean sum of squares due to environmental variation $\left(\sigma^{2} \mathrm{e}\right)$ among individuals of each genotype and $r$ is the number of replications.

Heritability percentage $\left(\mathrm{H}^{2)}\right.$ in broad sense was calculated by formula

$\mathrm{H}^{2}=100 \times \sigma^{2} \mathrm{~g} / \sigma^{2} \mathrm{p}$

Genotypic and phenotypic co-efficient (GCV and PCV) were estimated as:

$\mathrm{GCV}=100 \times \sigma^{2} \mathrm{~g} / \mathrm{x}$

$\mathrm{PCV}=100 \mathrm{x} \sigma^{2} \mathrm{p} / \mathrm{x}$

Whereas $\mathrm{x}$ is the general mean

Genetic gain (GA) is the difference between the mean of the progeny of selected individuals (Xp) and the base populations (Xo) was calculated by formulae

$\mathrm{GA}=\mathrm{i} . \mathrm{H}^{2} . \sigma^{2} \mathrm{p}$ or $\mathrm{H} \times \sigma \mathrm{g}$

Where $\mathrm{i}$ is the standardized selection differential $(5 \%)=2.06$

$\mathrm{H}^{2}=$ heritability i.e. $\sigma^{2} \mathrm{~g} / \sigma^{2} \mathrm{p}$

$\sigma p=$ phenotypic standard deviation 
$\sigma \mathrm{g}=$ genotypic standard deviation

$\mathrm{H}=$ standard deviation of heritability

In order to compare genetic component of particular year significance from the average of 10 years, critical difference was calculated following Singh and Chaudhary (1985)

\section{Results and Discussion}

\section{Seed cotton yield}

Genotypic coefficient of variation (GCV) for seed cotton yield ranged from 33.85 (2006) to $71.83 \%$ (2010). Genotypic coefficient of variation $(\mathrm{GCV})$ was more than $50 \%$ during the years 2003, 2005, 2008, 2009, 2010 and 2012 indicating high genotypic variation among the entries sponsored during these years. However, it was significantly higher than average over the ten years $58.67 \mathrm{~kg} / \mathrm{ha}$ $(51.49+7.18)$ only for the year 2010 . Phenotypic coefficient variation for seed cotton yield varied from 36.71 (2006) to $74.02 \%$ (2010). It was more than $50 \%$ for the years 2003, 2005, 2007, 2008, 2009, 2010 and 2012. It was significantly higher than average over the ten years $60.23 \mathrm{~kg} / \mathrm{ha}(53.08+7.15)$ only for the years 2003 and 2010. This suggested to create phenotypic and genotypic variability for the materials being sponsored in initial evaluation trial of $G$. hirsutum (irrigated). For all the years of this character PCV values were higher as compare to corresponding GCV values indicating preponderance of environmental variation over genotypic variation. Heritability in broad sense was very high in all the years ranging from 85.04 to $99.46 \%$. It was significantly higher than average over the ten years $96.62 \%$ $(93.85+2.77)$ for the years 2009 and 2011 suggesting comparatively lesser influence of environment during these years as also indicated by comparatively lower PCV and GCV during 2011. Genetic gain was high for seed cotton yield for all the years ranging from
417.88 (2006) to 897.83 (2003). It was significantly more than average over ten years $732.78(612.18+120.60)$ for the years 2003 , 2008 and 2012. During these years heritability was also very high but not significantly higher than the average over ten years suggesting the possibility of effective selection of genotypes sponsored by the breeders during these years (Table 1).

The seed cotton yield was the highest during 2003 followed by 2012 and 2008 exceeding significantly from the average over the ten years of the highest seed cotton yield 2905.31 $\mathrm{kg} / \mathrm{ha}(2533.11+372.20)$. In other years, seed cotton yield was below the average. During the years 2012 and 2008 also the seed cotton yield was not significantly higher than year 2003 indicating that over the years expected progress has not been achieved for enhancing of the seed cotton yield. The range of seed cotton yield is shown in Table 1. Similarly, the yearly mean seed cotton yield was significantly higher than over the ten years average of seed cotton yield of $1446.89 \mathrm{~kg} / \mathrm{ha}$ $(1237.31+209.58)$ for the years 2003,2004 and 2012 and in all other years it was lower than this value. Similarly, during the years 2012 also the mean seed cotton yield was not significantly higher than year 2003 suggesting that over the years expected progress has also not been achieved for enhancing of the seed cotton yield above the average over the years and the cotton breeders need to pay attention in this direction though every year based on the average performance of the cultivar, the best performing cultivars vis-a-vis the check varieties are being promoted after ranking in the yield potential and then released based on their over the years performance (Table 1).

\section{Ginning outturn percent}

For this trait genotypic coefficient of variation (GCV) ranged from 3.53 (2004) to 7.13\% (2007). It was very low during all the years 
indicating low genotypic variation among the entries sponsored during all the years. However, it was significantly higher than average over the ten years $5.71 \%(5.03+$ 0.68 ) for the years 2003 and 2007. Phenotypic coefficient variation for ginning outturn ranged from 4.45 (2009) to $10.22 \%$ (2007). It was also of low value for all the years as was observed for genotypic coefficient of variation and was significantly higher than average over the ten years $7.23 \%(5.95+1.28)$ for the years 2007 and 2008. This suggested to create phenotypic and genotypic variability for this trait of the entries being sponsored in initial evaluation trial of $G$. hirsutum (irrigated). During all the years for this character PCV values were higher as compare to corresponding GCV values indicating preponderance of environmental variation over genotypic variation. Heritability in broad sense varied from 43.60 to $99.01 \%$ and was more than 50\% for all the years except 2007 and 2008. It was significantly higher than average over the ten years $92.14 \%(77.27+$ 14.87) for the years 2009, 2011 and 2012 suggesting comparatively lesser influence of environment during these years as also indicated by comparatively lower PCV and GCV during 2011. Genetic gain was low for ginning outturn for all the years ranging from 0.90 (2004) to 2.36 (2007). It was significantly more than average over ten years $1.81(1.53+$ 0.28 ) only for the year 2007. During 2007 the heritability was comparatively low suggesting the possibility of effective selection of genotypes sponsored by the breeders during this year. Ginning outturn percent was significantly higher than the average over the ten years of the highest ginning outturn percent of $39.57 \%(37.79+1.78)$ only of the year $2007(44.13 \%)$. Similarly, the yearly mean GOT\% was significantly more than over the years average GOT\% of $34.52(33.54+$ 0.98) for the years 2006 and 2009 and in all other years it was lower than this value indicates slight progress in enhancement of ginning outturn percent. The study suggests that breeders should also pay attention for improvement of GOT\% (Table 2).

\section{Lint yield}

Genotypic coefficient of variation (GCV) for lint yield varied from 34.95 (2006) to 73.04\% (2010). Genotypic coefficient of variation (GCV) was more than $50 \%$ during the years 2003, 2008, 2009, 2010 and 2012 indicating high genotypic variation among the entries sponsored during these years. However, it was significantly higher than average over the ten years $59.14 \mathrm{~kg} / \mathrm{ha}(52.06+7.08)$ only for the year 2010. Phenotypic coefficient variation for lint yield ranged from 37.70 (2006) to $75.34 \%$ (2010). It was more than $50 \%$ for the years 2003, 2005, 2007, 2008, 2009, 2010 and 2012. It was significantly higher than average over the ten years $61.64 \mathrm{~kg} / \mathrm{ha}(54.24+7.40)$ for the years 2003 and 2010. This suggested to create phenotypic and genotypic variability for the materials being sponsored in initial evaluation trial of G. hirsutum (irrigated). For this character PCV values were higher as compare to corresponding GCV values for all the years indicating preponderance of environmental variation over genotypic variation.

Heritability in broad sense was very high in all the years ranging from 78.94 to $99.54 \%$. It was significantly higher than average over the ten years $96.48 \%(92.29+4.19)$ for the years 2009 and 2011 suggesting comparatively lesser influence of environment during these years as also indicated by comparatively lower PCV and GCV during 2011. Genetic gain was high for lint yield for all the years ranging from 152.20 (2007) to 300.05 (2012). It was significantly more than average over ten years $241.34(206.12+35.22)$ for the years 2003, 2008 and 2012. During these years heritability was also very high but not significantly higher than the average over ten years suggesting the 
possibility of effective selection of genotypes sponsored by the breeders during these years (Table 3).

The Lint yield (kg/ha) was highest during 2003 followed by 2012 exceeding significantly from the average over the ten years of the highest lint yield $979.18 \mathrm{~kg} / \mathrm{ha}$ $(856.70+122.43)$. For all other years the highest lint yield $\mathrm{kg} / \mathrm{ha}$ was less than this value indicating that limited progress has been achieved for enhancing the lint yield. The average lint yield $\mathrm{kg} / \mathrm{ha}$ over the years was significantly higher for the years 2003 (516.78 $\mathrm{kg} / \mathrm{ha}), 2004$ (540.87 kg/ha) and 2012 (542.53 $\mathrm{kg} / \mathrm{ha}$ ) exceeding the value $491.30 \mathrm{~kg} / \mathrm{ha}$ $(418.12+73.18)$. This reflects that no remarkable progress has been made over the years for lint yield $\mathrm{kg} / \mathrm{ha}$ which is a product of GOT\% and seed cotton yield (Table 3).

The low values shown in the range in respect of seed cotton yield, ginning outturn percent and lint yield $\mathrm{kg} / \mathrm{ha}$ is for genotypes developed in central or south zone of the country which were low yielder in north zone conditions.

\section{Boll no. per plant}

Genotypic coefficient of variation (GCV) for this trait ranged from 8.01 (2012) to $34.24 \%$ (2011). Genotypic coefficient of variation (GCV) was therefore low for all the years as it was not more than $50 \%$ indicating low genotypic variation among the entries sponsored during these years for this trait. It was significantly higher than average over the ten years 23.18 bolls/ plant $(18.56+4.62)$ only for the year 2011. Phenotypic coefficient variation for boll no. per plant varied from 11.25 (2012) to $35.33 \%$ (2011). It was less than $50 \%$ for all the years as that of genotypic coefficient of variation. It was significantly higher than average over the ten years 25.02 bolls/ plant $(20.73+4.29)$ only for the year 2011. This suggested to create phenotypic and genotypic variability of this trait for the materials being sponsored in initial evaluation trial of $G$. hirsutum (irrigated). For all the years for this character PCV values were higher as compare to corresponding GCV values indicating preponderance of environmental variation over genotypic variation. Heritability in broad sense was very high in all the years ranging from 50.77 to $93.90 \%$. It was significantly higher than average over the ten years $88.36 \%(78.55+$ 9.81) for the years 2009 and 2011 suggesting comparatively lesser influence of environment during these years. Genetic gain was low for boll no. per plant for all the years varying from 2.28 (2012) to 7.24 (2003). It was significantly more than average over ten years $6.74(5.48+1.26)$ for the years 2003, 2004, 2008 and 2011. During these years heritability was also very high but not significantly higher than the average over ten years suggesting the possibility of effective selection of genotypes sponsored by the breeders during these years.

The boll no. per plant were significantly higher during the years 2003 (61.55), 2004 (56.44) and 2005 (66.11) in comparison to average of the highest boll no. per plant over the ten years $54.81(45.61+9.20)$ and was lowest during the years 2009 and afterwards indicating that efforts be made to enhance this component in the forth coming years. The average boll no. per plant over the ten years was $41.93(34.14+7.79)$ and during 2003, 2004 and 2005 it exceeded significantly this value as shown in Table 4. This further suggested improving the boll no. per plant in the forth coming period.

\section{Boll weight}

Genotypic coefficient of variation (GCV) for Boll weight ranged from 7.07 (2008) to $16.24 \%$ (2003). Genotypic coefficient of variation $(\mathrm{GCV})$ was less than $50 \%$ during all the years indicating low to moderate genotypic variation among the entries sponsored during all the years. 
Table.1 Genetic component analysis of seed cotton yield (kg/ha) during 2003-2012 under AICCIP sponsored G. hirsutum material for initial evaluation

\section{Seed cotton yield (kg/ha)}

\begin{tabular}{|c|c|c|c|c|c|c|c|c|c|}
\hline Year & $\begin{array}{c}\sigma 2 \mathrm{~g} \\
\text { (Genotypic } \\
\text { variance) }\end{array}$ & $\begin{array}{c}\text { б2p(Phenotypic } \\
\text { variance) }\end{array}$ & $\begin{array}{c}\text { GCV } \\
\% \text { (Genotypic } \\
\text { coefficient of } \\
\text { variation) }\end{array}$ & $\begin{array}{c}\text { PCV (Phenotypic } \\
\text { coefficient of } \\
\text { Variation) }\end{array}$ & $\begin{array}{l}\text { Genetic } \\
\text { gain }\end{array}$ & $\begin{array}{c}\text { h2 (Heritability } \\
\text { in broad } \\
\text { sense) } \%\end{array}$ & Mean & Range & Range \\
\hline 2003 & 856904.14 & 910915.10 & 58.45 & $60.27 *$ & $897.83^{*}$ & 94.07 & $1583.66^{*}$ & 252.77 & $3536.09 *$ \\
\hline 2004 & 425658.40 & 466541.38 & 41.72 & 43.68 & 623.18 & 91.24 & $1563.77 *$ & 291.66 & 2664.43 \\
\hline 2005 & 329857.39 & 356301.23 & 50.26 & 52.23 & 552.61 & 92.58 & 1142.77 & 210.55 & 2297.76 \\
\hline 2006 & 205349.87 & 241486.35 & 33.85 & 36.71 & 417.88 & 85.04 & 1338.70 & 422.22 & 2255.54 \\
\hline 2007 & 200504.56 & 207659.16 & 49.64 & 50.52 & 446.48 & 96.56 & 902.02 & 151.39 & 1902.77 \\
\hline 2008 & 639563.10 & 671821.70 & 56.82 & 58.23 & $780.29 *$ & 95.20 & 1407.58 & 116.67 & 2936.63 \\
\hline 2009 & 250658.40 & 252019.70 & 51.39 & 51.53 & 499.30 & $99.46^{*}$ & 974.22 & 223.88 & 2057.10 \\
\hline 2010 & 305628.50 & 324585.60 & $71.83^{*}$ & $74.02 *$ & 536.45 & 94.16 & 769.66 & 54.16 & 2097.21 \\
\hline 2011 & 274094.40 & 281826.10 & 46.57 & 47.22 & 516.31 & $97.26^{*}$ & 1124.14 & 444.46 & 2441.66 \\
\hline 2012 & 724131.89 & 779518.17 & 54.32 & 56.36 & $851.44^{*}$ & 92.89 & $1566.58^{*}$ & 97.22 & $3141.93^{*}$ \\
\hline Mean & 421235.07 & 449267.45 & 51.49 & 53.08 & 612.18 & 93.85 & 1237.31 & 226.50 & 2533.11 \\
\hline $\begin{array}{c}\mathrm{CD} \\
(\mathrm{P}=\mathbf{0 . 0 5}) *\end{array}$ & 165581.79 & 176492.72 & 7.18 & 7.15 & 120.60 & 2.77 & 209.58 & 92.51 & 372.20 \\
\hline
\end{tabular}


Table.2 Genetic component analysis of ginning outturn (\%) during 2003-2012 under AICCIP sponsored G. hirsutum material for initial evaluation Ginning Out Turn (\%)

\begin{tabular}{|c|c|c|c|c|c|c|c|c|c|}
\hline Year & $\begin{array}{c}\sigma 2 \mathrm{~g} \\
\text { (Genotypic } \\
\text { variance) }\end{array}$ & $\begin{array}{c}\text { б2p(Phenotypic } \\
\text { variance) }\end{array}$ & $\begin{array}{c}\text { GCV } \\
\% \text { (Genotypic } \\
\text { coefficient of } \\
\text { variation) }\end{array}$ & $\begin{array}{c}\text { PCV (Phenotypic } \\
\text { coefficient of } \\
\text { Variation) }\end{array}$ & $\begin{array}{l}\text { Genetic } \\
\text { gain }\end{array}$ & $\begin{array}{l}\text { h2 (Heritability } \\
\text { in broad } \\
\text { sense) } \%\end{array}$ & Mean & Range & Range \\
\hline 2003 & 3.59 & 4.85 & $5.88 *$ & 6.84 & 1.63 & 73.89 & 32.22 & 27.81 & 37.35 \\
\hline 2004 & 1.48 & 2.68 & 3.53 & 4.75 & 0.90 & 55.26 & 34.45 & 31.77 & 36.78 \\
\hline 2005 & 2.88 & 3.61 & 5.24 & 5.87 & 1.52 & 79.78 & 32.36 & 29.44 & 35.93 \\
\hline 2006 & 2.68 & 3.03 & 4.60 & 4.89 & 1.54 & 88.46 & $35.64 *$ & 30.52 & 38.41 \\
\hline 2007 & 5.55 & 11.40 & $7.13^{*}$ & $10.22 *$ & $2.36 *$ & 48.68 & 33.03 & 29.42 & $44.13 *$ \\
\hline 2008 & 2.49 & 5.70 & 5.00 & $7.57 *$ & 1.04 & 43.60 & 31.54 & 28.80 & 35.60 \\
\hline 2009 & 2.31 & 2.41 & 4.35 & 4.45 & 1.49 & $95.85^{*}$ & $34.90 *$ & 30.53 & 39.20 \\
\hline 2010 & 2.66 & 2.98 & 5.03 & 5.33 & 1.54 & 89.26 & 32.41 & 27.50 & 36.20 \\
\hline 2011 & 3.00 & 3.03 & 5.05 & 5.07 & 1.72 & $99.01 *$ & 34.31 & 31.47 & 36.17 \\
\hline 2012 & 2.41 & 2.44 & 4.50 & 4.53 & 1.55 & $98.89 *$ & 34.49 & 30.70 & 38.10 \\
\hline Mean & 2.91 & 4.21 & 5.03 & 5.95 & 1.53 & 77.27 & 33.54 & 29.80 & 37.79 \\
\hline $\begin{array}{c}C D \\
(P=0.05) *\end{array}$ & 0.76 & 1.93 & 0.68 & 1.28 & 0.28 & 14.87 & 0.98 & 1.03 & 1.78 \\
\hline
\end{tabular}


Table.3 Genetic component analysis of lint yield (kg/ha) during 2003-2012 under AICCIP sponsored $G$. hirsutum material for initial evaluation

\begin{tabular}{|c|c|c|c|c|c|c|c|c|c|}
\hline \multicolumn{10}{|c|}{ Lint yield (kg/ha) } \\
\hline Year & $\begin{array}{c}\sigma 2 \mathrm{~g} \\
\text { (Genotypic } \\
\text { variance) }\end{array}$ & $\begin{array}{c}\sigma 2 p(\text { Phenotypic } \\
\text { variance) }\end{array}$ & $\begin{array}{c}\text { GCV } \\
\% \text { (Genotypic } \\
\text { coefficient of } \\
\text { variation) }\end{array}$ & $\begin{array}{c}\text { PCV } \\
\text { (Phenotypic } \\
\text { coefficient of } \\
\text { Variation) }\end{array}$ & $\begin{array}{c}\text { Genetic } \\
\text { gain }\end{array}$ & $\begin{array}{c}\text { h2 (Heritability } \\
\text { in broad } \\
\text { sense) } \%\end{array}$ & Mean & Range & Range \\
\hline 2003 & 88185.36 & 111711.00 & 57.46 & $64.68 *$ & $263.84 *$ & 78.94 & $516.78 *$ & 84.22 & $1142.35^{*}$ \\
\hline 2004 & 53191.19 & 58262.95 & 42.64 & 44.63 & 220.37 & 91.30 & $540.87 *$ & 90.16 & 977.14 \\
\hline 2005 & 33536.15 & 36297.89 & 49.83 & 51.84 & 176.02 & 92.39 & 367.50 & 65.91 & 690.47 \\
\hline 2006 & 28744.62 & 33435.31 & 34.95 & 37.70 & 157.20 & 85.97 & 485.05 & 128.61 & 861.83 \\
\hline 2007 & 22109.90 & 23279.24 & 50.00 & 51.31 & 152.58 & 94.98 & 297.38 & 52.79 & 662.28 \\
\hline 2008 & 65643.30 & 68880.70 & 57.01 & 58.40 & $250.12 *$ & 95.30 & 449.43 & 34.60 & 915.81 \\
\hline 2009 & 31656.80 & 31802.50 & 52.07 & 52.19 & 177.51 & $99.54 *$ & 341.67 & 79.63 & 694.55 \\
\hline 2010 & 34034.82 & 36212.27 & $73.04 *$ & $75.34 *$ & 178.85 & 93.99 & 252.58 & 17.39 & 684.75 \\
\hline 2011 & 35019.90 & 35955.90 & 48.30 & 48.94 & 184.68 & $97.40^{*}$ & 387.42 & 139.87 & 856.17 \\
\hline 2012 & 90037.00 & 96757.56 & 55.31 & 57.33 & $300.05^{*}$ & 93.05 & $542.53 *$ & 33.14 & $1082.14 *$ \\
\hline Mean & 48215.90 & 53259.53 & 52.06 & 54.24 & 206.12 & 92.29 & 418.12 & 72.63 & 856.75 \\
\hline $\begin{array}{c}\mathrm{CD}(\mathrm{P}=0.05) \\
*\end{array}$ & 17576.77 & 21277.98 & 7.08 & 7.40 & 35.22 & 4.19 & 73.18 & 28.42 & 122.43 \\
\hline
\end{tabular}


Table.4 Genetic component analysis of boll no. per plant during 2003-2012 under AICCIP sponsored $G$. hirsutum material for initial evaluation

\begin{tabular}{|c|c|c|c|c|c|c|c|c|c|}
\hline \multicolumn{10}{|c|}{ Boll No./plant } \\
\hline Year & $\begin{array}{c}\sigma 2 \mathrm{~g} \\
\text { (Genotypic } \\
\text { variance) }\end{array}$ & $\begin{array}{c}\sigma 2 p(\text { Phenotypic } \\
\text { variance })\end{array}$ & $\begin{array}{c}\text { GCV } \\
\% \text { (Genotypic } \\
\text { coefficient of } \\
\text { variation) }\end{array}$ & $\begin{array}{c}\text { PCV (Phenotypic } \\
\text { coefficient of } \\
\text { Variation) }\end{array}$ & $\begin{array}{l}\text { Genetic } \\
\text { gain }\end{array}$ & $\begin{array}{c}\text { h2 (Heritability } \\
\text { in broad } \\
\text { sense) } \%\end{array}$ & Mean & Range & Range \\
\hline 2003 & 63.82 & 77.78 & 16.53 & 18.25 & $7.24 *$ & 82.05 & $48.33 *$ & 31.33 & $61.55^{*}$ \\
\hline 2004 & 62.92 & 78.14 & 17.99 & 20.05 & $7.12 *$ & 80.52 & $44.09 *$ & 26.89 & $56.44 *$ \\
\hline 2005 & 63.12 & 109.43 & 15.19 & 20.00 & 6.03 & 57.68 & $52.31 *$ & 36.22 & $66.11 *$ \\
\hline 2006 & 32.92 & 39.77 & 17.71 & 19.47 & 5.22 & 82.78 & 32.39 & 17.33 & 46.06 \\
\hline 2007 & 15.30 & 18.84 & 16.96 & 18.82 & 3.16 & 81.21 & 23.06 & 14.33 & 30.00 \\
\hline 2008 & 54.75 & 63.95 & 19.30 & 20.86 & $6.85^{*}$ & 85.61 & 38.34 & 21.20 & 53.33 \\
\hline 2009 & 17.52 & 18.83 & 18.08 & 18.75 & 4.04 & $93.04 *$ & 23.15 & 14.46 & 31.86 \\
\hline 2010 & 39.90 & 51.17 & 21.61 & 24.47 & 5.58 & 77.98 & 29.26 & 7.73 & 40.06 \\
\hline 2011 & 56.33 & 59.99 & $34.24 *$ & $35.33 *$ & $7.27 *$ & $93.90 *$ & 21.92 & 29.23 & 37.20 \\
\hline 2012 & 5.22 & 10.28 & 8.01 & 11.25 & 2.28 & 50.77 & 28.51 & 18.27 & 33.47 \\
\hline Mean & 41.18 & 52.82 & 18.56 & 20.73 & 5.48 & 78.55 & 34.14 & 21.70 & 45.61 \\
\hline $\mathrm{CD}(\mathrm{P}=0.05) *$ & 15.71 & 22.20 & 4.62 & 4.29 & 1.26 & 9.81 & 7.79 & 6.30 & 9.20 \\
\hline
\end{tabular}


Table.5 Genetic component analysis of boll weight (g) during 2003-2012 under AICCIP sponsored $G$. hirsutum material for initial evaluation

\begin{tabular}{|c|c|c|c|c|c|c|c|c|c|}
\hline \multicolumn{10}{|c|}{ Boll weight (g) } \\
\hline Year & $\begin{array}{c}\sigma 2 \mathrm{~g} \\
\text { (Genotypic } \\
\text { variance) }\end{array}$ & $\begin{array}{c}\sigma 2 p(\text { Phenotypic } \\
\text { variance) }\end{array}$ & $\begin{array}{c}\text { GCV } \\
\% \text { (Genotypic } \\
\text { coefficient of } \\
\text { variation) }\end{array}$ & $\begin{array}{c}\text { PCV } \\
\text { (Phenotypic } \\
\text { coefficient of } \\
\text { Variation) }\end{array}$ & $\begin{array}{l}\text { Genetic } \\
\text { gain }\end{array}$ & $\begin{array}{c}\text { h2 (Heritability } \\
\text { in broad } \\
\text { sense) } \%\end{array}$ & Mean & Range & Range \\
\hline 2003 & 0.23 & 0.27 & $16.24^{*}$ & 17.65 & 0.44 & $84.64 *$ & 2.93 & 1.97 & 3.89 \\
\hline 2004 & 0.14 & 0.19 & 11.67 & 13.73 & 0.32 & 72.25 & 3.18 & 2.37 & 4.03 \\
\hline 2005 & 0.05 & 0.16 & 7.47 & 14.11 & 0.40 & 28.04 & 2.87 & 2.15 & 3.41 \\
\hline 2006 & 0.11 & 0.19 & 11.31 & 14.77 & 0.26 & 58.62 & 2.98 & 2.35 & 4.20 \\
\hline 2007 & 0.25 & 0.29 & $14.88 *$ & 16.51 & 0.53 & 82.20 & $3.36 *$ & 2.50 & 3.97 \\
\hline 2008 & 0.03 & 0.09 & 7.07 & 12.29 & 0.60 & 33.33 & 2.45 & 1.90 & 2.90 \\
\hline 2009 & 0.16 & 0.17 & 11.56 & 14.44 & $1.80 *$ & $94.12 *$ & $3.46^{*}$ & 2.53 & $4.36^{*}$ \\
\hline 2010 & 0.13 & 0.14 & 11.82 & 12.21 & 0.35 & $92.86^{*}$ & 3.05 & 2.30 & 3.67 \\
\hline 2011 & 0.08 & 0.13 & 8.87 & 11.45 & 0.22 & 61.54 & 3.19 & 2.20 & 3.67 \\
\hline 2012 & 0.26 & 0.54 & $15.08 *$ & $21.74 *$ & 0.50 & 48.15 & $3.38 *$ & 2.70 & $4.70 *$ \\
\hline Mean & 0.14 & 0.22 & 10.85 & 14.13 & 0.54 & 65.58 & 3.09 & 2.30 & 3.88 \\
\hline $\mathrm{CD}(\mathrm{P}=0.05) *$ & 0.06 & 0.09 & 2.23 & 2.49 & 0.32 & 16.71 & 0.21 & 0.18 & 0.36 \\
\hline
\end{tabular}


It was significantly higher than average over the ten years $13.08 \mathrm{~g}(10.85+2.23)$ for the years 2003, 2007 and 2012. Phenotypic coefficient variation for Boll weight varied from 11.45 (2011) to $21.74 \%$ (2012). It was also less than $50 \%$ for all the years and was significantly higher than average over the ten years $16.62 \mathrm{~g}$ $(14.13+2.49)$ for the years 2003 and 2012 . This also suggested to create phenotypic and genotypic variability for the materials being sponsored in initial evaluation trial of $G$. hirsutum (irrigated). PCV values for all the years were higher as compare to corresponding GCV values indicating preponderance of environmental variation over genotypic variation. Heritability in broad sense was ranged from 28.04 to $94.12 \%$. It was significantly higher than average over the ten years $82.29 \%(65.58+16.71)$ for the years 2003, 2009 and 2010 suggesting comparatively lesser influence of environment during these years. Genetic gain was low for Boll weight for all the years ranging from 0.22 (2011) to 1.80 (2009). It was significantly more than average over ten years $0.86(0.54+0.32)$ only for the year 2009. Boll weight showed moderate estimates of phenotypic and genotypic coefficients of variation indicating diversity among the material studied depicting the possibility of improvement in the boll weight in future period.

The boll weight significantly exceeded over the ten years average of the highest boll weight i.e. $4.24 \mathrm{~g}(3.88+0.36)$ during the years 2009 (4.36 $\mathrm{g})$ and $2012(4.70 \mathrm{~g})$ indicating that progress for this component has been made by the breeders. The average boll weight over the ten years was $3.30 \mathrm{~g}(3.09+0.21)$ and during 2007, 2009 and 2012 it exceeded significantly this value as shown in Table 5.

During 2003 seed cotton yield, lint yield and boll no. per plant were significantly higher than average over the ten years whereas in 2012 seed cotton yield, lint yield and boll weight were significantly higher than this average. The results obtained are in broad agreement with the findings of Valarmathi and Jehangir (1998),
Ahuja and Tuteja (2000) and Rao and Reddy (2001). In general the differences between PCV and GCV were less for all the traits indicating that these traits were not influenced by the environment to greater extent thus suggesting ample scope for improvement through selection (Neelima and Reddy, 2008). Johnson et al., (1955) indicated that high values of heritability are not always an indication of high genetic gain. Swarup and Chaugale (1962) also showed that high heritability is not always an indicator of genetic gain. If heritability is mainly due to non-additive gene effect, the expected genetic advance would be low, and if there is additive gene effect, a high genetic advance may be expected (Panse 1957). In the present investigation high heritability coupled with high genetic gain was observed for seed cotton yield and lint yield indicating the operation of additive gene action in the inheritance of these traits for the material sponsored by the breeders of the country in the initial evaluation trial of $G$. hirsutum (irrigated). High $\mathrm{H}^{2}$ with expected response to selection also revealed that the genetic variances play important role in inheritance and establishment of these traits. High broad sense heritability $\left(\mathrm{H}^{2}\right)$ and genetic gain were also recorded for seed cotton yield $(0.98,643.16 \mathrm{~kg})$ by Khan et al., (2009). High heritability coupled with moderate genetic gain was observed for boll no. per plant and low genetic gain and high heritability was observed for ginning outturn percent and boll weight indicating the operation of both additive and non-additive gene action in the inheritance of these traits. The present findings are in broad agreement with the results reported by Valarmathi and Jehangir (1998), Ahuja and Tuteja (2000), Rao and Reddy (2001) and Ganesan and Raveendran (2004).

High broad sense heritability and genetic gain were recorded by Ranganatha et al., (2013) for bolls plant per plant $(0.81,8.04)$, boll weight $(0.78 \mathrm{~g}, 1.02 \mathrm{~g})$ and seed cotton yield per plant $(0.87 \mathrm{~g}, 34.06 \mathrm{~g})$, respectively. Their results suggested that rigorous genotypic selection is required to identify desirable genotypes for these traits. 


\section{Acknowledgements}

The author acknowledges the support from Director, Central Institute for Cotton Research, Nagpur, Head of the Station, Central Institute for Cotton Research, Sirsa and Project Coordinator cum Head, Central Institute for Cotton Research, Coimbatore for conducting the experiment.

\section{References}

Ahuja S L and Tuteja O P. 2000. Variability and association analysis for chemical components imparting resistance in Gossypium hirsutum cotton. J. Cotton Res. and Dev. 14: 19-22.

Basal $\mathrm{H}$ and Turgut I. 2005. Genetic analysis of yield components and fiber strength in Upland cotton (G. hirsutum L.). Asian J. Plant Sci. 4(3): 293-298.

Basbag S and Gencer O. 2004. Investigations on the heritability of seed cotton yield, yield components and technological characters in cotton (G. hirsutum L.). Pak. J. Biol. Sci. 7(8): 1390-1393.

Ganesan K N and Raveendran T S. 2004. Genetic variability studies on fibre quality traits and seed cotton yield in $\mathrm{F}_{2}$ and $\mathrm{F}_{3}$ generations of cotton (Gossypium hirsutum L.). Int. Symposium on "Strategies for Sustainable Cotton Production- A Global Vision" 1. Crop Imp., 23-25 Nov 2004, University of Agricultural Sciences, Dharwad, Karnataka (India), pp: 191-192.

Johnson H W, Robinson H F and Comstock R E. 1955. Estimates of genetic and environmental variability in soybean. Agron. J. 47: 314-318.
Khan N U, Hassan G, Khan B M, Farhatullah, Batool S, Makhdoom K, Khan I, Khan I A and Ahmad W. 2009. Genetic Variability and Heritability in Upland Cotton. Pak. J. Bot. 41(4): 1695-1705.

Neelima S and Chenga Reddy V. 2008. Genetic parameters of yield and fibre quality traits in american cotton (Gossypium hirsutum 1.). Indian J. Agric. Res. 42 (1): 67-70.

Panse V C and Sukhatme P V. 1978. Statistical methods for Agricultural workers. III Rev. Ed. ICAR, New Delhi.

Ranganatha H M, Shreekanth S Patil, Manjula S M and Arvind kumar B N. 2013. Genetic Variability Studies in Segregating Generation of Upland Cotton (Gossypium hirsutum L.) Molecular Plant Breeding, 2013, Vol. 4, No. 10.

Rao G N and Reddy M S. 2001. Studies on heritability and variability for yield and its component in cotton (Gossypium hirsutum L.). J. Cotton Res. Dev. 15(1), 84-86.

Singh R K and Chaudhary B D. 1985. Biometrical methods in Quantitative Genetic Analysis. Kalyani Publishers, New Delhi.

Swarup V and Chaugale D S. 1962. Studies on genetic variability in sorghum I. Phenotypic variation and its heritability component in some important characters contributing towards yield. Indian $J$. Genet. 22: 31-36.14.

Valarmathi and Jehangir K S. (1998). Studies on genetic parameters for yield and fibre quality traits in inter varietal crosses of cotton (G. hirsutum). J. Indian Soc. Cot. Improv. 23: 64-67.

\section{How to cite this article:}

Ahuja, S.L., S.K. Sain, R.A. Meena and Sarfraz Ahmad. 2018. Genetic Component Analysis for a Decade of G. hirsutum Cotton Breeding Material Sponsored in All India Coordinated Cotton Improvement Project. Int.J.Curr.Microbiol.App.Sci. 7(10): 1396-1408. doi: https://doi.org/10.20546/ijcmas.2018.710.155 